\title{
Identificación y selección de indicadores de factores socio-educacionales que afectan la calidad de los servicios
}

\author{
Identification and selection of indicators of socio-educational factors that \\ affect the quality of services \\ Hamed Enshaei ${ }^{1}$, Hamdollah Manzari Tavakoli ${ }^{2 a}$, Sanjar Salajegheh ${ }^{3}$, \\ Masoud Pourkiani ${ }^{4}$ y Hojat Babaei ${ }^{5}$ \\ Islamic Azad University, Kerman, Iran ${ }^{12345}$ \\ iD Orcid ID: https://orcid.org/0000-0002-8278-0914 ${ }^{1}$ \\ Orcid ID: https://orcid.org/0000-0003-1651-3663² \\ Orcid ID: https://orcid.org/0000-0002-3412-6731 3 \\ Orcid ID: https://orcid.org/0000-0002-5370-3768 \\ Orcid ID: https://orcid.org/0000-0002-8084-4507
}

Recibido: 11 de febrero de 2020

Aceptado: 13 de agosto de 2020

\begin{abstract}
Resumen
Los municipios de la provincia de Mazandaran (Irán), como otras organizaciones de servicios, están trabajando dentro de los marcos legales. A la luz de la creciente importancia de la satisfacción del cliente y su respeto en los municipios, el objetivo de este artículo es identificar y evaluar los indicadores de los factores sociales que afectan la calidad de los servicios. La población estadística del presente estudio incluyó expertos y profesores universitarios en la provincia de Mazandaran. 15 personas fueron seleccionadas por un método de muestreo no aleatorio. Con base en estudios previos, la literatura de investigación y las entrevistas realizadas, el cuestionario fue diseñado y aprobado. De 36 preguntas sobre los factores sociales que afectan la calidad de los servicios, 7 estaban relacionadas con la calidad de los servicios. El examen de los ítems del cuestionario se realizó con el enfoque de la técnica Delphi y la idoneidad de los componentes y dimensiones se midió utilizando el software SPSS. De acuerdo con los resultados de la segunda ronda de la técnica Delphi, 33 indicadores de factores sociales que afectan la calidad de los servicios y 5 indicadores de calidad de servicio obtuvieron una puntuación superior a 3. Los servicios basados en los criterios propuestos por los expertos incluyeron el comportamiento de los empleados, además de su competencia y habilidades, la innovación en la prestación de servicios, la coordinación y la responsabilidad de la organización, la confianza organizacional, el desempeño organizacional, la responsabilidad social y los valores laborales de los empleados. Además, la media de todas las dimensiones estaba entre 4 y 5 (entre apropiado y completamente apropiado). En conclusión, hubo un ajuste entre todas las dimensiones de los factores sociales que afectan la calidad de los servicios según los criterios propuestos.
\end{abstract}

Palabras clave: Factores sociales, calidad del servicio, organizaciones de servicio, expertos, técnica Delphi. 


\begin{abstract}
Municipalities in Mazandaran province (Iran), like other service organizations, are working within legal frameworks. In light of the increasing importance of customer satisfaction and respect in municipalities, the objective of this article is to identify and evaluate indicators of social factors that affect the quality of educational services. The statistical population of the present study included experts and university professors in the Mazandaran province. 15 people were selected by a non-random sampling method. Based on previous studies, research literature, and interviews conducted, the questionnaire was designed and approved. Of 36 questions on social factors that affect the quality of educational services, 7 were related to the quality of educational services. The examination of the items of the questionnaire was carried out with the Delphi technique approach and the suitability of the components and dimensions was measured using the SPSS software. According to the results of the second round of the Delphi technique, 33 indicators of social factors that affect the quality of educational services and 5 indicators of quality of service obtained a score higher than 3 . The educational services based on the criteria proposed by the experts included the behavior of the employees, in addition to their competence and skills, innovation in the provision of educational services, coordination and responsibility of the organization, organizational trust, organizational performance, social responsibility and the labor values of employees. Furthermore, the mean of all dimensions was between 4 and 5 (between appropriate and completely appropriate). In conclusion, there was an adjustment between all dimensions of social factors that affect the quality of educational services according to the proposed criteria.
\end{abstract}

Keywords: Social factors, service quality, service organizations, experts, Delphi technique.

\title{
Introduction
}

Since the role of educational services in the daily lives of human beings was revealed, the issue of "quality of service" has also been considered among organizations. The quality of educational services is recognized as the main component of the success in an organization in today's competitive environment, and any decrease in customer satisfaction with the organization due to poor quality of service is a concern. Nowadays, the quality of educational services is an important and effective factor in the success and failure of organizations, including municipalities (Mohammadi \& Bakhtiari, 2015). In other words, quality of service is defined as the measurement of performance against expectations or the gap between expectations and perception of educational services (Shahriar, 2013). The problem of quality of service is created in organizations that do not pay attention to recognizing customer needs and meeting them. Due to limited resources that affect all organizations, including municipalities, managers must first identify the needs and expectations of their customers and then measure their perceptions of educational services received, the gap between the expectations and perceptions of their customers and finally select the most cost-effective solutions to fill the existing gap (Bahadori et al., 2013). Nowadays, in a competitive world, customers are at the center of attention of service organizations such as municipalities and their satisfaction is the main factor in gaining the competitive advantage of organizations, so 
customer satisfaction plays a vital role in achieving the organization's goals in new business processes (Habibipour \& Karimzadeh (2012).

Also, providing high-quality educational services requires the ability to control quality at all times and the ability to solve specific problems that may arise (Pariza, 2014). It leads to increased productivity and customer satisfaction and reduces organizational costs. Quality of service is the largest problem of service organizations, so all organizations, especially service organizations, such as municipalities, should seek to improve the quality of their educational services (Mohammadnia et al., 2010). In the literature of educational services, the importance of quality of service and its relationship with customer satisfaction has been strongly emphasized.

Researchers state that high quality of educational services is a prerequisite for customer satisfaction. Having a knowledge of the concept of quality of service and efforts to improve it will lead to the provision of quality educational services, and increasing the level of quality of educational services leads to increased customer satisfaction (Safiek et al., 2014). The great efforts are nowadays made by researchers, experts, and managers of organizations to improve performance management tools and expand customer-oriented attitudes, indicating that customer satisfaction is currently one of the most important factors in determining the success of organizations (Matoubi \& Talebi, 2015). The municipality is one of the institutions of civil society, which is one of the developmental and participatory structures of the country within the framework of governance in the social, local and urban areas in the constitution (Hedayat \& Elmi, 2012). Municipalities will succeed in achieving their goals and maintaining a balance between present and future needs if they consider the satisfaction of the citizens. Satisfaction of the citizens will make them actively participate in fulfilling the duties and responsibilities and the participation of the citizens is considered as the core of decision making. Citizens' satisfaction is a key factor in continuous improvement in the work process to increase efficiency and improve the quality of comprehensive urban management (Mohammadi \& Bakhtiari, 2015).

Municipalities in Mazandaran province, like other service organizations, are working within legal frameworks. Increasing the importance of customer satisfaction and respecting them in municipalities, especially the municipalities of Mazandaran province, requires identifying and removing barriers of providing high-quality service and improving the process of providing service. Accordingly, the issue of customer satisfaction in this organization is one of the important factors and customer dissatisfaction results from a gap between customer expectations and the performance of municipalities in Mazandaran province, as customer perceptions (Sari, 2019). Thus, given what was stated above, the aim of this article is to identify and screen indicators of social factors affecting the quality of educational services. 


\section{Methodology}

The present work was developmental in terms of objective and descriptive in terms of nature. It was conducted using library method (based on past studies, research literature) and qualitative (interview) method. The statistical population of the study included experts who were familiar with the subject of quality of educational services. Their number was unknown and scattered throughout the country, so they were selected purposefully and by considering the characteristics such as knowledge and experience in the subject, willingness, sufficient time to participate in the study, and effective communication skills (Ahmadi, 2009), having scientific research and articles related to the subject of research, availability, experience, appropriateness of the field of study, $\mathrm{PhD}$ level of education, and teaching at the university.

To select an appropriate sample from the population of experts and university professors of Mazandaran province, a non-random purposeful sampling method was used. Accordingly, to select the appropriate sample, 15 people were selected from the population of experts and university professors who met the research inclusion criteria. Based on previous studies, the research literature and interviews conducted, the model was designed and approved and out of 36 questions on the social factors affecting the quality of educational services, 7 questions were related to quality of educational services. In the mentioned questionnaire, respondents were asked to determine the importance of each of the items.

This questionnaire is scored based on a five-point Likert scale, ranging from "completely inappropriate" option to a "completely appropriate" option. After obtaining the opinion of the experts using the approach of Delphi technique, the number of items of the questionnaire of social factors affecting the quality of educational services changed to 33 , and the questionnaire of quality of educational services changed to 5 items. To assess the result of survey of the research experts, the mean fit of the dimensions with the desired variable and the mean fit of the components with the desired dimensions were examined using SPSS software.

\section{Results}

Based on past studies, the research literature and interviews, a total of 33 indicators (criteria and sub-criteria) were identified. In the first step of Delphi technique, these criteria were first provided to experts and they were asked to provide suggestions on integrating some of the criteria into a new one, and finally, no indicator was added to sub-criteria. 
In the second step of the Delphi technique, 33 indicators of social factors affecting the quality of educational services were first screened to select the criteria that were more important and appropriate. Then, each of the criteria were reviewed by experts of this field, who were composed of 15 people and were familiar with all the sub-indicators. Delphi technique was used for the initial screening of identified criteria. Delphi's technique continued in two rounds, and in the second round, it was stopped when expert reached a final agreement. Finally, the remaining 33 indicators in the second round obtained score above 3 again. Thus, the Delphi technique was stopped and the indicators of social factors affecting the quality of educational services were used for the final analysis.

\section{Identification and screening indicators of quality of service}

Based on previous studies, the research literature and interviews, a total of 5 indicators were identified. In the first step of Delphi technique, these criteria were provided for experts of this field and they were asked to provide suggestions on integrating some of the criteria into a new one, and finally, no

In the second step of the Delphi technique, 5 quality of service indicators were first screened to select the criteria that are more important and appropriate. Then, each of the criteria were reviewed and examined by 15 experts who were familiar with all the sub-indicators, according to Delphi technique.

Delphi's technique continued in two rounds, and in the second round, it was stopped when expert reached a final agreement. Finally, the remaining 5 indicators in the second round obtained score above 3 again. Thus, the Delphi technique was stopped and the indicators of social factors affecting the quality of educational services were used for the final analysis.

\section{Reviewing the results of a survey of experts}

Question 1: What are the components of social factors affecting the quality of educational services in the municipalities of Mazandaran province?

Dimensions and components of social factors affecting the quality of educational services based on the proposed criteria of experts include employees' behavior, competence and skills of employees, innovation in providing service, coordination and accountability of the organization, organizational trust, organizational performance, social responsibility and employees' work values. According to (Table 1), the mean of all dimensions is between 4 and 5 (between appropriate and completely appropriate) and this means that according to the experts of this research, there is a fit between all dimensions of social factors affecting the quality of educational services based on the proposed criteria. 


\section{Table 1}

Mean fit of dimensions of social factors affecting the quality of educational services

\begin{tabular}{lll}
\hline Variable & Dimension & $\begin{array}{l}\text { mean fit of dimension } \\
\text { with variable }\end{array}$ \\
\hline $\begin{array}{l}\text { social factors affecting } \\
\text { the quality of } \\
\text { educational services }\end{array}$ & $\begin{array}{l}\text { Employees' behavior } \\
\text { Competence and skills of } \\
\text { employees }\end{array}$ & 4.314 \\
& $\begin{array}{l}\text { Innovation in providing } \\
\text { service }\end{array}$ & 4.107 \\
& $\begin{array}{l}\text { Coordination and } \\
\text { accountability of the } \\
\text { organization }\end{array}$ & \\
& $\begin{array}{l}\text { Organizational trust } \\
\text { Organizational } \\
\text { performance }\end{array}$ & 4.097 \\
& Social responsibility & 4.325 \\
& Employees' work values & 4.604 \\
\hline
\end{tabular}

Question 1-1: What are the components of employees' behavior in the municipalities of Mazandaran province?

According to Table 2, the mean of all dimensions is between 4 and 5 (between appropriate and completely appropriate) and it means that according to the experts of this research, there is a fit among all dimensions of employees' behavior based on the proposed criteria.

\section{Table 2}

Mean fit among dimensions of educational employees' behavior

\begin{tabular}{lll}
\hline Variable & Dimension & $\begin{array}{l}\text { Mean fit of dimension } \\
\text { with variable }\end{array}$ \\
\hline $\begin{array}{l}\text { Employees' } \\
\text { behavior }\end{array}$ & $\begin{array}{l}\text { Staff commitment and } 4.400 \\
\text { conscientiousness }\end{array}$ \\
& $\begin{array}{l}\text { The level of willingness to help } 4.333 \\
\text { and respond to the customer }\end{array}$ \\
& $\begin{array}{l}\text { Having skill of negotiation and } 4.600 \\
\text { providing information to the } \\
\text { customer }\end{array}$
\end{tabular}


Question 1-2: What are the components of employees' skill and competence in the municipalities of Mazandaran province?

According to Table 3, the mean of all dimensions is between 4 and 5 (between appropriate and completely appropriate) and it means that according to the experts of this research, there is a fit among all dimensions of employees' skill and competence based on the proposed criteria.

\section{Table 3}

Mean fit among dimensions of educational employees' skill and competence

\begin{tabular}{lll}
\hline Variable & Dimension & $\begin{array}{l}\text { Mean fit of dimension } \\
\text { with variable }\end{array}$ \\
\hline $\begin{array}{l}\text { Employees' skill } \\
\text { and competence }\end{array}$ & Employees' professional knowledge and skills & 4.333 \\
& $\begin{array}{l}\text { Mastery of employees at work } \\
\text { Employees' politeness and ability to build trust and } \\
\text { assure the customer }\end{array}$ & 4.600 \\
\hline
\end{tabular}

Question 1-3: What are the components of innovation in providing service in the municipalities of Mazandaran province?

According to Table 4, the mean of all dimensions is between 4 and 5 (between appropriate and completely appropriate) and it means that according to the experts of this research, there is a fit among all dimensions of innovation in providing service based on the proposed criteria.

Table 4

Mean fit among dimensions of innovation in providing educational service

\begin{tabular}{|lll} 
Variable & Dimension & $\begin{array}{l}\text { Mean fit of dimension } \\
\text { with variable }\end{array}$ \\
\hline $\begin{array}{l}\text { Innovation in } \\
\text { providing } \\
\text { educational services }\end{array}$ & $\begin{array}{l}\text { Reducing the use of written and manual } 4.467 \\
\text { documents } \\
\text { Development of technological and } 4.733 \\
\text { electronic educational services } \\
\text { Providing accurate information to the } 4.600 \\
\text { customer by an informed person }\end{array}$ \\
\hline
\end{tabular}


Question 1-4: What are the components of coordination and accountability in organization in the municipalities of Mazandaran province?

According to Table 5, the mean of all dimensions is between 4 and 5 (between appropriate and completely appropriate) and it means that according to the experts of this research, there is a fit among all dimensions of coordination and accountability in organization based on the proposed criteria.

Table 5

Mean fit among dimensions of coordination and accountability in organization

\begin{tabular}{lll}
\hline Variable & Dimension & $\begin{array}{l}\text { Mean fit of dimension } \\
\text { with variable }\end{array}$ \\
\hline $\begin{array}{l}\text { Coordination and } \\
\text { accountability of organization }\end{array}$ & $\begin{array}{l}\text { The division of tasks among } \\
\text { employees }\end{array}$ & 4.333 \\
& $\begin{array}{l}\text { Interaction and coordination among } \\
\text { administrative departments }\end{array}$ & \\
& Employees' social participation & 4.467 \\
&
\end{tabular}

Question 1-5: What are the components of organizational trust in the municipalities of Mazandaran province?

According to Table 6, the mean of all dimensions is between 4 and 5 (between appropriate and completely appropriate) and it means that according to the experts of this research, there is a fit among all dimensions of organizational trust based on the proposed criteria.

Table 6

Mean fit among dimensions of organizational and educational trust

\begin{tabular}{lll}
\hline Variable & Dimension & $\begin{array}{l}\text { Mean fit of dimension } \\
\text { with variable }\end{array}$ \\
\hline Organization trust & Lateral trust & 4.400 \\
& Vertical trust & 4.267 \\
& $\begin{array}{l}\text { Institutional } \\
\text { trust }\end{array}$ & 4.200 \\
& \\
\hline
\end{tabular}

Question 1-6: What are the components of organizational performance in the municipalities of Mazandaran province? 
According to Table 7, the mean of all dimensions is between 4 and 5 (between appropriate and completely appropriate) and it means that according to the experts of this research, there is a fit among all dimensions of organizational performance based on the proposed criteria.

\section{Table 7}

Mean fit among dimensions of organizational and educational performance

\begin{tabular}{lll}
\hline Variable & Dimension & $\begin{array}{l}\text { Mean fit of dimension } \\
\text { with variable }\end{array}$ \\
\hline $\begin{array}{l}\text { Organizational } \\
\text { performance }\end{array}$ & Productivity & 4.333 \\
& Efficiency & 4.533 \\
& Effectiveness & 4.333 \\
\hline
\end{tabular}

Question 1-7: What are the components of social responsibility in the municipalities of Mazandaran province?

According to Table 8, the mean of all dimensions is between 4 and 5 (between appropriate and completely appropriate) and it means that according to the experts of this research, there is a fit among all dimensions of social responsibility based on the proposed criteria.

Table 8

Mean fit among dimensions of social and educational responsibility

\begin{tabular}{lll}
\hline Variable & Dimension & $\begin{array}{l}\text { Mean fit of dimension } \\
\text { with variable }\end{array}$ \\
\hline $\begin{array}{l}\text { Social } \\
\text { responsibility }\end{array}$ & Economic responsibility & 4.267 \\
& Legal responsibility & 4.200 \\
& Moral responsibility & 4.267 \\
& $\begin{array}{l}\text { Optional and voluntary } \\
\text { responsibility }\end{array}$ & 4.333 \\
\end{tabular}

\section{Discussion}

According to experts, the items presented as components of social factors affecting the quality of educational services are classified in 8 general categories, including employees' behavior, employees' competence and skills, innovation in providing service, coordination and accountability of the organization, organizational trust, organizational performance, social responsibility, and employees' work values. According to the results, the employees' behavior in the municipalities of Mazandaran province included three factors of commitment and conscientiousness of employees, the level of willingness to help and respond to the customer, and having skill of negotiation and providing information to the customer. These results are in 
line with the results of the study conducted by (Varghese, 2019) who showed that all five variables of reliability, responsiveness, assurance, empathy, tangible factors, development of technological and electronic educational services, social participation of employees, social responsibility have a positive effect on customer satisfaction (Varghese, 2019). It was found that the employees' competence and skills in the municipalities of Mazandaran province included three factors of employees' professional knowledge and skills, mastery of employees at work, politeness and ability of employees to build trust and assure the customers). These results are in line with the results of the studies conducted by (Rasouli \& Maghsoudpour, 2016) who showed that there was a relationship between channel marketing and its factors (completeness of educational services, transportation management, the way of collecting receivables, technology, micro and pristine markets) and quality of educational services provided (Rasouli \& Maghsoudpour, 2016). These results are also in line with the results of the study conducted by (Palangard et al., 2016) who showed that improvement in educational services received by customers is one of the reasons for the profitability of bodybuilding clubs that offer educational services beyond the expectations of their athletes and they have more satisfied and loyal customers. They also showed that the quality of service leads to customer satisfaction and customer satisfaction will lead to increased loyalty and customer retention. As mentioned, the quality of provided educational services can be one of most important factors influencing customer loyalty (Palangard et al., 2016).

It was found that innovation in providing educational services in the municipalities of Mazandaran province included three factors of reduced use of written and manual documents, mastery of employees at work, providing accurate information to the customer by an informed person). These results are in line with those of the research conducted by (Sari, 2019) showed that the quality of provided educational services and mental image of customers had a positive and significant effect on the loyalty of the customers of Tehran Refah Bank and the quality of the educational services had a positive and significant effect on the mental image of the customers and the mediating role of mental image of customers in the relationship between the quality of provided educational services and customer loyalty was confirmed (Sari, 2019).

For the other hand, it was found that the coordination and accountability of the organization in the municipalities of Mazandaran province included three factors of division of tasks among employees, interaction and coordination among administrative departments, and social participation of employees). These results are in line with those of the research conducted by Bindal et al (2015) who showed quality of banking educational services through gap analysis technique in different dimensions of quality and can show key items to improve performance (Choi et al., 2016). It was found that organizational trust in the municipalities of Mazandaran province included three factors of lateral trust, vertical trust, and institutional trust. These results 
are in line with the results of the research conducted by (Sanjuq, 2014) who showed reliability, assurance, empathy and responsiveness did not have a strong relationship with customer satisfaction, but the tangible aspects of quality of service had a positive effect on customer satisfaction (Sanjuq, 2014). It was found that organizational performance in the municipalities of Mazandaran province included three factors of productivity, efficiency, effectiveness. These results are in line with those of the studies conducted by (Tiregar et al., 2013) who showed a significant relationship between ergonomic level and quality of service in Zahedan (Tiregar et al., 2013).

\section{Conclusion}

It was found that social responsibility in the municipalities of Mazandaran province included four factors of economic responsibility, legal responsibility, moral responsibility, and optional and voluntary responsibility). These results are in line with those of the study conducted by (Afghanpour \& Hasiri, 2013) showed 5 dimensions of quality of service had a significant effect on employees' job satisfaction (Afghanpour \& Hasiri, 2013). It was found that employees' work values in the municipalities of Mazandaran province included three factors of job satisfaction, organizational commitment, strong desire to participate in affairs. These results are in line with those of the research conducted by (Fahimnia \& Mantegh, 2013) who showed the effect of service provided by librarians, information control, space and place, and order and coordination had a significant relationship with the dependent variable of trust in librarians. Among these variables, the variable of the effect of service provided by librarians had the strongest relationship with trust in librarians. They also showed that the independent variables entered in the regression equation predicted $45 \%$ of the variance of the dependent variable (Fahimnia \& Mantegh, 2013). It was found that the quality of educational services in the municipalities of Mazandaran province included five factors of tangible factors, reliability, responsiveness, assurance, and empathy). Also, the reliability and empathy component were in good status and tangible factor was ranked the lowest among them (Mirzazadeh et al., 2013).

\section{References}

Afghanpour, M. \& Aghapour-Hasiri S. (2013). Investigating the relationship between job satisfaction of employees and quality of educational services within the framework of SERVQUAL Model: Case Study: Furniture Manufacturing Workshops in Babol. The first national conference on business management, Hamedan, Tolu-e Farzin Science and Technology Company, Bu Ali Sina University, 18(2): 121-136.

Ahmadi N. (2009). Webqual model is an approach to developing a conceptual model in improving the quality of website educational services. Journal of Librarianship and 
Informing, 4(8): 53-72.

Bahadori M., Zaboli R. \& Ghanbari A. (2013). Investigating the quality of educational services provided in Hamadan Armed Forces Medical Educational services Branch from the perspective of veterans. Science-Research Journal of Veterinary Medicine, 6(21): 4450.

Choi T., Kim D. \& Ha J. (2016). A Stabilization Model for E-Government Innovation. 49th Hawaii International Conference On System Sciences (pp. 3011-3020). Hawaii: IEEE Computer Society, 16(1): 251-261.

Fahimnia, F. \& Mantegh H. (2013). Investigating the relationship between the quality of educational services provided in university libraries and the generalized level of students' trust in librarians. Journal of Librarianship and Informing, 16(4): 59-79.

Habibipour, H. \& Daei Karimzadeh S. (2012). Investigating and designing a customer relationship model with an approach of psychology of cashiers and its evaluation in the branches of Tejarat Bank, Isfahan. 4th International Conference on Banking Educational services Marketing, Tehran: Financial Educational services Marketing Center, 19(3): 54-60.

Hedayat, R. \& Elmi, M. (2012). Investigating the level of citizens' satisfaction with the performance of urban educational services and related socio-economic factors in Naqadeh city. Journal of Sociological Studies, 5(16): 29-47.

Matoubi P. \& Talebi D. (2015). Evaluating the quality of educational services provided to students of Abadan Islamic Azad University. First International Conference on Psychology and Educational Sciences, Shiraz: Hakim Orfi Higher Institute of Science and Technology, 8(6): 240-252.

Mirzazadeh, Z., Moazami M. \& Nemati S. (2013). Investigating the quality of service provided in Torqabeh and Shandiz sports complexes. Ministry of Science, Research and Technology - Ferdowsi University of Mashhad - Faculty of Physical Education, Sports Sciences, 6(1): 130-147.

Mohammadi, F. \& Bakhtiari, F. (2015). Theoretical model of the relationship between organizational intelligence and quality of service. Police Organizational Development, 5(2): 69-84.

Mohammadnia M., Delgoshaei B., Tofighi S., Rihai L. \& Omrani A. (2010), Nursing Educational services Quality in Hospitals of Social Security Organization Using Servqual Model, Hospital Journal, 8(3): 68-74.

Momeni-Yaneh, S. M. (2019). Investigating the impact of quality of educational services provided on customer loyalty with mediating role of customer image (Case study: Refah Bank Employees in Tehran). Islamic Azad University - Shahroud Branch - Faculty of Literature and Humanities, 18(2): 136-153. 
Naseri-Palangard, V., Sadeghi-Boroujerdi, S., Yousefi, B. \& Sadeghi-Kalani, A. (2016). The effect of the quality of educational services provided on customer loyalty of bodybuilding clubs based on the SERVQUAL model (with the mediating role of customer satisfaction). The First National Conference on the Development of Sports Science in the Fields of Health, Prevention and Championship, 23(2): 174-198

Pariza, N. (2014). The analysis of perception of master students regarding the quality of educational services of Bucharest universities, Procedia Economics and Finance, 15(1): 746-751.

Rasouli R. \& Maghsoudpour N. (2016). Investigating the relationship between channel marketing and the quality of banking educational services provided. International Conference on New Horizons in Management and Accounting Sciences, Economics and Entrepreneurship, Tehran, Association of Science and Technology New Horizons, 16(1): 74-89.

Safiek R., Abu Hasan Z. \& Yadi-Yaakop A. (2014). Tertiary students' Assessment of Service Quality in the Malaysian Banking Industry: An Importance-Performance Analysis. Mediterranean Journal of Social Sciences, 5(1): 361-398.

Sanjuq, G. (2014): The Impact of Service Quality Delivery on Customer Satisfaction in the banking Sector in Riyadh, Saudi Arabia. International Journal of Business Administration, 5(4): 32-39.

Shahriar, A. (2013). Development and validation of an instrument to measure user perceived service quality of Health. Information and Management, 50(4): 181-195.

Tiregar, H., Hossein Zehi Zamani M. \& Vaezi, Z (2013). The relationship between ergonomics and quality of service in Zahedan Municipality. First National Conference on Urban and Environmental Educational services, 17(1): 441-460.

Varum-Varghese, A. (2019), Impact of ICT on multitasking during travel and the value of travel time savings: Empirical evidences from Mumbai, India. Journal of Travel Behaviour and Society, 12(6): 11-22. 